\title{
Ecotourism Management for Development Countries
}

\author{
ALEKSANDRA B. VIDOVIĆ, Pan-European University APEIRON, \\ College of Modern Management, Banja Luka, \\ Bosnia and Herzegovina
}

Review paper

UDC: $338.48-44(497.6)$

$005.412: 338.48$

DOI: 10.5937/tehnika1802293V

\begin{abstract}
The development of eco-tourism plays a major role in the tourist offer of the Republic of Bosnia and Herzegovina, as mass tourism is losing in importance and gives way to a segmental tourism and guest structure changes and age. Provides an overview of future activities, and where the potential of the tourist offer lies, as well as an overview of the current situation in Bosnia and Herzegovina. The main objective of this paper is to determine whether eco-tourism impact on economic development, the possibility of evaluation of natural resources and adaptation to the demands of modern tourism. Based on the foregoing subject of research will consider the possibility of organizing modern forms ecotourism. The paper tested the null hypothesis where $H_{0}$ - There are no statistically significant differences between the group "Employees" and the "Unemployed" in terms of their attitude in terms of ecotourism. $H_{1^{-}}$ There are significant differences between the group "Employees" and the "Unemployed" in terms of their attitude in terms of their position on the eco-tourism.
\end{abstract}

Key words: management, ecotourism, business and economic development

\section{INTRODUCTION}

Eco-tourism is a rather vague term that partly resembles a marketing gimmick, a part does have a foothold in the behavior of tourists who consider themselves eco-tourists. In fact, it is a form of tourism in which participating ecologically conscious individuals and groups, whose actions are trying to reduce the environmental effects of what creates the so-called mass tourism [3].

In the sixties of this century, there was a belief that tourism creates/increase foreign exchange and employment levels, spending by tourists generates a multiplier effect that stimulates the local economy. In recent years, it is evident that there is a slight increase in the rate of economic and economic growth, which largely depends on the recovery of production here talking about a simple and expanded reproduction, where simple reproduction is the process of production, which is updated in one scale, while the expanded reproduction refers to where renewed production at a higher

Author's address: Aleksandra Vidović, Pan-European University APEIRON, College of Modern Management, Banja Luka, Pere Krece 13, Bosnia and Herzegovina

e-mail: aleksandra.v@aperion-uni.eu

Paper received: 27.12.2017.

Paper accepted: 16.02.2018. level compared to the previous year. Economic development is continuously finding the optimal combination between factors of production (labor, land, capital) on the basis of mutual competitiveness.

Money supply growth opens up a different development process. It reduces the interest rate, encourages economic development, but in the end shows the growth of inflation. So here shows that the economy is composed of opposing trends (by operation of law of supply and demand) and all the skill and wisdom in establishing relationships and fine fine decision [6].

Many authors see tourism as a science, art and business, tourism is seen as attracting visitors, providing comfortable accommodation and hosting. Tourism as a business entity provided places and events with the aim of taking over people while on vacation, tourism is seen as a source of relaxation. The fact is that tourism increases social relationship which means that it could influence the attitude and behavior between, and thus influence social change.

The World Tourism Organization (2009) simply defines tourists as people who "travel and staying in places outside their usual environment - no more years in a row, in their leisure, business and other purposes" $[9,10]$.

Research initially functioned as an instrument for development where most of the research performed by 
planners and economists who worked for organizations such as the UN, World Bank, OECD.

Tourism in this era of global hailed leisure activities. The World Tourism Organization UNWTO (2011) in the analysis that was made popular tourism explained through an example that this sector in 2010, there were over 940 million international tourist arrivals, with a growth of $6.6 \%$ compared to 2009 . "The development of technology, education, cultural awareness of people influences the choice of destination as well as technology and computer literacy is so advanced that even the most remote destinations are no longer so far away and that the exchange and processing of data is done so quickly from all over the world. Considering the fact I think that the best answer to give to the world tourist organization where it says that in the time that comes to us will be current five trends: eco-tourism, cultural tourism, thematic tourism, adventure tourism, cruises.

Modification of old and creation of new demands of tourists yet, unseen destinations underlines the fact that tourism is an area in globalization. The journey from one to the other end of the world is not a big problem for tourists [12].

Regarding the valuation of the tourism sector - the evaluation is done in the following way, first you need to find a good enough or adequately example and to analyze the relative value of the given offer, following on what you need to pay attention to assess / view premium offered in that particular period, and do comparison with the previous premiums in a long period, usually taken the time period from the previous three months.

Rural areas are suffering immense changes and because of that it is important to save their authenticity: tour guides might serve as bridges that could contribute in understanding that way of living and rural tourism is a tool to show tourist all these intangible and tangible heritage [1].

Rural tourism is important for sustainable development of rural areas, which abets the preservation of local identity, tradition, and customs; it protects the environment, strengthens the traditional and organic farming and helps the development of rural areas based on sustainable development [5].

\section{LITERATURE REVIEW}

Is unavoidable to say that tourism industries that are currently registered the highest growth, specific data indicate that currently $58 \%$ of the world tourist industry waste in Europe and is on the first place.

When talking about the origins of the modern tourist industry - often used the name of cultural tourism - is believed to have started in a Grand Tour. Grand
Tour - an early form and precursor of modern tourism, There are new and clear civil-related structures: that are primarily focused on educational expansion, completion of education, adoption and development of sophisticated knowledge and manners [8]. Grand Tour will be held in major European cities (e.g. Paris, Milan and Rome) in order to further develop made modern hotels and other services to potential guests. Question modern hotel primarily refers to the creation of socalled eco-hotel. In terms of designing the future of the tourist offer and future activities one can freely say that they are just forms of modern tourism is becoming more and more frequently mentioned in the literature business tourism.

Forms of modern tourism is often divided into:

- Ecotourism;

- Business meetings;

- Public conferences;

- Meetings;

- Travel;

Often in the literature meet the unique term that refers to the above forms of modern tourism-business tourism or the so-called business tourism does not have any particular major differences compared to the classic tourism. Some of these differences can be reflected in the reduction of tourists is usually seasonal, or sieve so may affect the extension of the season if it has already been a meeting who were at the very end of the season or just starting after the end of the season [4].

Eco content and demand eco tourism demand is characterized by a general need for facilities that guarantee eco image - whether it guarantees that offer ecoactivities was to guarantee that the use of any content does not pollute the environment in which they will stay a potential tourist.

The World Tourism Organization (WTO) predicts tourism growth to 1.6 billion trips by 2020 , and the traffic around US \$ 2 billion for the Mediterranean country's WTO predicts a decrease in market share from $30 \%$ to $22 \%$ or increase visits a year by $3 \%$ to 167 million 1995 to 346 million in 2020 .

In 2013 there was an increase of $2.4 \%$ of tourism in Europe, travel to developed countries increased by more than $3.0 \%$ between 2012 and 2013, a trip to developing countries fell slightly $(-0,8 \%)$. This slight decrease is probably due to continued economic uncertainty in 2013, allowing travelers spend less on holiday.

However, economic recovery and Europe as well as search for new, authentic destinations and experiences are expected, as well as new growth in Eurpean tourism and developing countries [2]. 


\section{The potential for the development of eco-tourism}

Bosnia and Herzegovina, with an area of 51,197 $\mathrm{km}^{2}$ represents a country that has great potentialpreserved environment, biodiversity, gorgeous landscapes and climatic and relief diversities for the development and promotion of tourism.

Regarding the potential of the tourism offer specifically in Bosnia and Herzegovina can be said that the republic is very rich channels spa tourism, mountain tourism, ecotourism, rural tourism, hunting and fishing tourism and religious tourism.

The historical legacy though a relatively small country, Bosnia and Herzegovina has a rich culture that has had a major impact on other countries in the Balkans. Enough clues that testify that a man settled here 2,500 years ago, primarily due to the excavation of copper and iron ores.

Natural resources becomes accentuated form of demand or the conditions and evidence that nature and human environment protection, which is evidence of concern for a healthy environment and healthy authentic food. This is the first market advantage B\&H. In Bosnia and Herzegovina there are quite isolated, but very hospitable communities in the villages. The optimum altitude, dense forests, meadows, caves, rock massifs, experiences in nature, especially in the mountains, the rivers and lakes and landscapes that are unique to the experience of nature and its flora and fauna, high quality air in our villages provide excellent conditions for tourists. Walking, hiking, rafting, skiing, picking herbs, are just part of the tourism demand, which will have an emphasis on nature and nature conservation. In Bosnia and Herzegovina has developed eco-tourism with a number of tourist centers which offer a unique environment and tourism offer, for example Sutjeska national park, the oldest rainforest in Europe Perućica, Maglić, national park Kozara, Jahorina, Pliva Lake, Blagaj and many others.

When analyzing the attractiveness of Bosnia and Herzegovina as a tourist destination, we see that this is a very interesting market segment, which is growing globally, and which is increasingly turning to nature and healthy lifestyle.

Therefore, in the tourist areas, the drilling of longterm economic and spatial urban general and detailed plans. In order to natural resources in the service of tourism optimally used, it is necessary to plan and manage the development of tourism carrying capacity assessment to introduce certain tourist areas [7].

The tourism sector in $\mathrm{B} \& \mathrm{H}$ recorded a positive trend for all the main indicators of growth in the last ten years but there is still significant room for further use its initial resources. The development of tourism in the Republic of Srpska was largely unorganized and this situation lasted until 2011, then comes to the harmonization and adoption of the „Strategy of development of tourism in the Republic of Srpska for the period 2011-2020" by the Assembly of the Republic of Serbian. This strategy was the principal but also the starting document for all future steps regarding developing potential. According to estimates, RS now has about 1.4 million inhabitants, which is about 200,000 inhabitants less than the number of inhabitants who lived in this area in 1991 year. Population decline is a result of falling birth rates and emigration expressed. In rural areas, there are about $50 \%$ of the population of RS. Investing in the development of individual accommodation facilities and the development of rural, ethno, eco, excursion and hunting tourism would provide positive economic effect in the income of rural households and any incentive village renewal and development of rural areas. Development of rural tourism requires financial support to rural households in order to strengthen the social status and improve the tourism offer (infrastructure services). This type of tourism involves measures necessary education of the local population. For more favorable economic basis, in which people can participate in tourist trends and invest in the development of tourism requires a revenue of at least $\$ 3,500$ per capita [11].

In the following figure provides an overview of the situation in the Republic of Bosnia and Herzegovina in terms of the number of arrivals to specific ecotourism destinations or visit the national park Sutjeska, Kozara national park, national park Una, Jahorina, there is an evident increase from year to year.

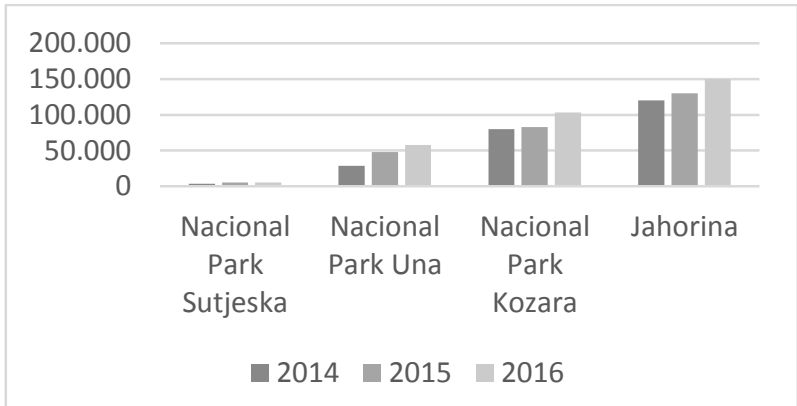

Figure 1 - The number of visits to tourism destinations in B\&H in the period 2014-2016

\section{RESEARCH METHODOLOGY}

Economic development should allow for constant growth in every aspect of developing a particular country. Today more and more important get so called popular places, and unspoiled nature. In such places offer services for a healthy life and use their spare time.

The research was conducted by survey on a sample of the population of the Republic of Srpska and the Federation of $\mathrm{B} \& \mathrm{H}$ between the ages of $18-50$ years 
old, the sample of respondents is representative, meaning that there were two groups of respondents, divided by groups, the first group consisted of respondents who are employed in the research facilitate alignment of data called the "employees" (have less time to explore these places), while the second group consisted of working age respondents, aged 18 years or are not employed, and another group called the „unemployed“ (have more time to explore these places).

After completing the survey research, the empirical data were analyzed by statistical programming Statplus2009 and SPSS 22. The purpose of this study was to determine the extent to which the premises of $\mathrm{RS} / \mathrm{B} \& \mathrm{H}$ there is interest in this form of tourism, depending on the level of employment.

The sample according to the type of system among the group of samples and included 130, however, it was found 18 questionnaires was wrong, and they are rejected, this kind of research is a type of qualitative research.

This structure allows the sample and subsequent filtering attitudes of respondents with additional information related to gender and age as well as sociodemographic characteristics. The sample was surveyed 112 respondents, over a period of 90 days in 2017.

The research was carried out so that the selected sample can be tested the following hypotheses:

$\mathrm{H}_{0}$-There are no statistically significant differences between the groups, „Employees“ and the „Unemployed" in terms of their attitude in terms of ecotourism.

$\mathrm{H}_{1}$ - There are significant differences between the group „Employees“ and the „Unemployed“ in terms of their attitude in terms of their position on the ecotourism.

The basic research questions which I dealt with in the work related to:

1. Ecotourism development opportunity of the Republic of Srpska and Bosnia and Herzegovina?

2. Do you believe that ecotourism is becoming more than enjoying the natural beauty and cultural heritage of a city or area (ethnic, religious, event happens)?

3. Do you think that organic production should be encouraged at the same time and eco tourism.

4. Before you will choose to break the sea or an ecotourism destination for example: gastronomy, etc.?

To test for the hypotheses used a non parametric statistical test Chi-square $\left(\chi^{2}\right)$ and to test the independence of the characteristics according to the following formula. $\chi^{02}=\Sigma \mathrm{i}=1 \mathrm{~m}(f \mathrm{i}-f \mathrm{i}(\mathrm{t})) 2 / f \mathrm{i}(\mathrm{t})$.

\section{RESULTS AND DISCUSSION}

The research was conducted at the territory of the city Banja Luka, studies have attempted to determine the attitudes of respondents on whether ecotourism can be a driver of development of the country, on a random sample of 112 respondents. If we analyze the demographic and socio-economic structure of the respondents were found to be 64 female respondents (71.68\%) and 48 males (28.32\%). Most respondents, $58.24 \%$ belongs to the age group of 26 to 50 years, while the other group consists of respondents age 18 to 25 years, with $41.76 \%$ of the respondents. According to the education level of respondents was highest with secondary education 45 of them (40.17\%), a high school diploma $35(31.25 \%)$ and college degree 32 $(28.57 \%)$. Employees $65(58,04 \%)$ and Unemployed $47(41,96 \%)$.

The survey was conducted during the month of May - July 2017 using a structured questionnaire in which there are questions about the specific opinions of the respondents.

The test results are shown in Tables 1 - 4.

Q1: Ecotourism development opportunity RS and the Federation of Bosnia and Herzegovina?

Table 1. Structure of respondents' answers (Q1)

\begin{tabular}{|l|l|l|l|l|}
\hline \multicolumn{5}{|l|}{$\begin{array}{l}\text { Analysis of Variance (One-Way)(ANOVA)- Alpha value } \\
\text { (for confidence interval) } 0,05<3.84\end{array}$} \\
\hline Groups & $\begin{array}{l}\text { Sample } \\
\text { size }\end{array}$ & Sum & Mean & Variance \\
\hline Variable \#1 & 2 & 73 & 36,5 & 144,5 \\
\hline Variable \#2 & 2 & 39 & 19,5 & 4,5 \\
\hline ANOVA & & & & \\
\hline $\begin{array}{l}\text { Source of } \\
\text { Variation }\end{array}$ & SS & $d f$ & MS & $F$ \\
\hline $\begin{array}{l}\text { Between } \\
\text { Groups }\end{array}$ & 289 & 1 & 289 & 3,8792 \\
\hline $\begin{array}{l}\text { Within } \\
\text { Groups }\end{array}$ & 149 & 2 & 74,5 & \\
\hline Total & 438 & 3 & & \\
\hline Chi-TEST & 0.357 & & & \\
\hline $\begin{array}{l}\text { Standard } \\
\text { error of } \\
\text { difference }\end{array}$ & 8.631 & & & \\
\hline p-level & 0.5501 & & & \\
\hline F crit & 998,5002 & & & \\
\hline t=1,9696 & & & & \\
\hline
\end{tabular}

As to whether ecotourism development opportunity for countries' attitudes are closely related but nevertheless there is no statistically significant difference as $\chi^{2}=0.357<\chi^{2}(0.05: 1)=3.84$ or Chi-square with Yates correction - Chi squared equals 0.357 with 1 degrees of freedom. The two-tailed $\mathrm{P}$ value equals 
0.5501. Confidence interval: The mean of Group One Group Two equals minus 17.00, 95\% confidence interval of this difference: From -20.14 to 54.14 null hypothesis $\mathrm{H}_{0}$ is accepted with a probability of $95 \%$ The association between rows (groups) and columns (outcomes) is considered to be not statistically significant. The same conclusion can be reached by comparing the $\mathrm{p}$ value with the value of risk mistakes. Since the je $\chi^{2}=0,357<3,84$, the null hypothesis $\mathrm{H}_{0}$ is accepted.

Q2. Do you think that ecotourism is becoming more than enjoying the natural beauty and cultural heritage of a city or area (ethnic, religious, event happens)?

Table 2. Structure of respondents' answers (Q2)

\begin{tabular}{|l|l|l|l|l|}
\hline \multicolumn{5}{|l|}{$\begin{array}{l}\text { Analysis of Variance (One-Way)(ANOVA)- Alpha value } \\
\text { (for confidence interval )0,05 }<3.84\end{array}$} \\
\hline Groups & $\begin{array}{l}\text { Sample } \\
\text { size }\end{array}$ & Sum & Mean & Variance \\
\hline Variable \#1 & 2 & 54 & 27 & 98 \\
\hline Variable \#2 & 2 & 23 & 11,5 & 0,5 \\
\hline ANOVA & & & & \\
\hline $\begin{array}{l}\text { Source of } \\
\text { Variation }\end{array}$ & SS & $d f$ & $M S$ & $F$ \\
\hline Between Groups & 240,25 & 1 & 240,5 & 4,8782 \\
\hline Within Groups & 98,5 & 2 & 49,5 & \\
\hline Total & 338,25 & 3 & & \\
\hline Chi-TEST & 1,5511 & & & \\
\hline $\begin{array}{l}\text { Standard error of } \\
\text { difference }\end{array}$ & 7.079 & & & \\
\hline p-level & 0.4601 & & & \\
\hline F crit & 998,5002 & & & \\
\hline t=0,9418 & & & & \\
\hline
\end{tabular}

Respondents believe that ecotourism is now more than enjoying the natural beauty and cultural heritage, the results are as follows: Chi squared equals 1.5511 with 1 degrees of freedom. The two-tailed $\mathrm{P}$ value equals 0.4601 . Confidence interval: The mean of Group One Group Two equals minus 6.67, 95\% confidence interval of this difference: From -12.99 to 26.32 .

The conclusion is given that $\chi^{2}=1.5511<\chi^{2}(0.05$ : 1) $=3.84$ and / or $p=0.4601>3.84$, the null hypothesis $\mathrm{H} 0$ is accepted with a probability of $95 \%$, by conventional criteria, this difference is considered to be not quite statistically significant.

Q3. Do you think that organic production should be encouraged at the same time and ecotourism.
Table 3. Structure of respondents' answers (Q3)

\begin{tabular}{|l|l|l|l|l|}
\hline \multicolumn{5}{|l}{$\begin{array}{l}\text { Analysis of Variance (One-Way)(ANOVA) - Alpha value } \\
\text { (for confidence interval) } 0,05<3.84\end{array}$} \\
\hline Groups & $\begin{array}{l}\text { Sample } \\
\text { size }\end{array}$ & Sum & Mean & $\begin{array}{l}\text { Varianc } \\
e\end{array}$ \\
\hline Variable \#1 & 2 & 70 & 35 & 8 \\
\hline Variable \#2 & 2 & 42 & 21 & 128 \\
\hline ANOVA & & & & \\
\hline $\begin{array}{l}\text { Source of } \\
\text { Variation }\end{array}$ & SS & $d f$ & MS & F \\
\hline Between Groups & 196 & 1 & 196 & 2,8824 \\
\hline Within Groups & 136 & 2 & 68 & \\
\hline Total & 332 & 3 & & \\
\hline Chi-TEST & 0.1138 & & & \\
\hline $\begin{array}{l}\text { Standard error of } \\
\text { difference }\end{array}$ & 10.770 & & & \\
\hline p-level & 0.1368 & & & \\
\hline F crit & 998,5002 & & & \\
\hline $\mathrm{t}=0,9285$ & & & & \\
\hline
\end{tabular}

The results of empirical research: Chi-square with Yates correction - Chi squared equals 0.1138 with 1 degrees of freedom. The two-tailed $\mathrm{P}$ value equals 0.1368 Confidence interval: The mean of Group One Group Two equals minus 10.00, 95\% confidence interval of this difference: From -36.34 to 56.34 . Considering that $\chi 2=0.1138<\chi 2(0.05: 1)=3.84$ and $/$ or $\mathrm{p}=0.1368>\alpha=0.05$, the null hypothesis $\mathrm{H} 0$ is accepted with a probability of $95 \%$, the association between rows (groups) and columns (outcomes) is not considered to be statistically significant.

Q4. Before you will choose to break the sea or an ecotourism destination for example: gastronomy, etc.?

Table 4. Structure of respondents' answers (Q4)

\begin{tabular}{|l|l|l|l|l|}
\hline \multicolumn{4}{|l}{$\begin{array}{l}\text { Analysis of Variance (One-Way)(ANOVA) - Alpha value (for } \\
\text { confidence interval) } 0,05<3.84\end{array}$} \\
\hline Groups & Sample size & Sum & Mean & Variance \\
\hline Variable \#1 & 2 & 63 & 31,5 & 40,5 \\
\hline Variable \#2 & 2 & 23 & 11,5 & 0,5 \\
\hline ANOVA & & & & \\
\hline $\begin{array}{l}\text { Source of } \\
\text { Variation }\end{array}$ & SS & $d f$ & MS & $F$ \\
\hline Between roups & 400 & 1 & 400 & 19,512 \\
\hline Within Groups & 41 & 2 & 20,5 & \\
\hline Total & 441 & 3 & & \\
\hline Chi-TEST & 1,6567 & & & \\
\hline $\begin{array}{l}\text { Standard error of } \\
\text { difference }\end{array}$ & 9.315 & & & \\
\hline p-value & 0.4367 & & & \\
\hline F crit & 998,5002 & & & \\
\hline t=0.7157 & & & & \\
\hline
\end{tabular}


When asked where the respondents would prefer to spend your vacation whether it is more or some eco destinations 78,40 respondents chose more, while $21.46 \%$ of respondents selected eco destination. Of the total number of respondents group „Employees“ respondents chose not to give $56.01 \%$, while the group „,being unemployed“ respondents also chose more of them $71.79 \%$. On the basis of the research is determined by Chi squared equals 1.6567 with 1 degrees of freedom. $P$ value and statistical significance: The twotailed $P$ value equals 0.4367 . By conventional criteria, this difference is not considered to be statistically significant, the null hypothesis $\mathrm{H} 0$ is accepted with a probability of $95 \%$.

\section{CONCLUSION}

To conclude that the presumption of tourism development may be reflected in the cultural differences that create opportunities for development and improvement of different forms of tourism (ethnic, religious, events). Which means that tourism relies on the rich culture of the ethnic communities in the form of preserved values of gastronomy, crafts, folklore, etc., Are just part of the rich tourist offer, for now still not wellestablished and valued.

Furthermore conclusion can also be that for a successful ecotourism in the function of economic development, to do this evaluation of comparison with the best, because only this type of business is the only and the best possible solution for the perception of ecotourism, as well as forecasting the direction in which to go further. The Federal Ministry of Environment and Tourism is already working on building a system of tourist flows in accordance with European standards, which allows the right to the protection of tourism, with the aim of economic and social development of Bosnia and Herzegovina.

Since the Republic of Bosnia and Herzegovina rich natural resources on the one hand but also the current trends prevailing are such that they are going to benefit the tourist offer, namely, the point is precisely that today's trend of "healthy lifestyle" can help us to create an image of an attractive ecotourism offer .

A survey regarding the understanding of the importance of ecotourism as a prerequisite for the development of the country confirmed the null hypothesis is set in four specific situations, which indicates that there is no statistically significant difference in the attitudes of respondents, while the other hypothesis is rejected.

\section{REFERENCES}

[1] Anđelković Ž, Dragin A, Božić S, Emotional Exhaustion and Job Satisfaction of Tour. Economics of Agriculture, 64(1), 11-26, 2017.

[2] CBI, Ministry of Foreing Affairs. CBI, Ministry of Foreing Affairs. CBI Trade Statistics, Tourism from Europe. CBI Market Intelligence. Hague: Ministry of Foreing Affairs, 2015.

[3] Eco tourism, Retrieved from wikipedia.org: https://bs.wikipedia.org/wiki/Eko_turizam, 2016,04.14.

[4] Gračan D, Rudančić-Lugarić A, Business tourism modern form for improvment of the competitiveness of Croatian tourism. Ekonomska misao i praksa(2), 579-590, Prosinac, 2011.

[5] Milojevic S, Pavlovic N, Entrepreneurial Spirit of Rural Tourism of the Pomoravlje Distric, Central Serbia . Ekonomika, Vol. 63(january-march), 63-72, 2017.

[6] Milojević A, Osnove ekonomije, Banja Luka: PanEuropean University Apeiron, 2012.

[7] Ministarstvo okoliša BIH. Strategija razvoja turizma Federacije Bosne i Hercegovine za period 20082018. Sarajevo: Ministarstvo okoliša BIH, 2008.

[8] Ueli G, Geschichte des Tourismus: Strukturen auf dem Weg zur Moderne. Retrieved from http://iegego.eu/de/threads/europa-unterwegs/tourismus/ueligyr-geschichte-des-tourismus, 2010, 03. 12.

[9] Vidovic A, Tourism in function of economic development. Uzice, 2013.

[10]Vidović A, Upravljanje prodajnim aktivnostima trgovačkih preduzeća u funkciji tržišne komunikacije, Moć Komunikacije - POWERCOM. (pp. 8-16). Beograd: Visoka strukovna škola za tržišne komunikacije, 2015.

[11]Vlada RS. Strategija razvoja turizma 2011-2020. Banja Luka: Vlada RS, 2011.

[12]Vučenović R, Pretpostavke za razvoj eko turizma u opštini. Icacus (p. 325). Banja Luka: Panevropski univerzitet Apeiron, 2011. 


\section{REZIME}

\section{RAZVOJ MODERNOG OBLIKA TURIZMA - EKOTURIZAM U UPRAVLJANJU RAZVOJEM DRŽAVE}

Razvoj ekoturizma ima veliku ulogu u turističkoj ponudi Republike Bosne i Hercegovine, jer masovni turizam gubi na značaju i ustupa mjesto segmentalnom turizmu a i struktura gostiju se mijenja, kao $i$ životna dob. Osnovni cilj rada je da se utvrdi da li ekoturizam utiče na privredni razvoj, mogućnost vrednovanja prirodnih potencijala, te prilagođavanje zahtjevima modernog turizma. Dat je pregled budućih aktivnosti, odnosno gdje leži potencijal turističke ponude, kao i pregled trenutnog stanja u Bosni $i$ Hercegovini. Na osnovu naprijed navedenoga predmet istraživanja predstavlja sagledavanje mogućnosti organizovanja modernih oblika ekoturizma. U radu je testirana postavljena nulta hipoteza gdje je $H_{0^{-}}$Ne postoje statistički značajne razlike između grupe „Zaposleni“ i grupe „Nezaposleni“ $u$ pogledu njihovog stava po pitanju ekoturizma. $H_{1^{-}}$Postoje statistički značajne razlike između grupe „Zaposleni“ i grupe „Nezaposleni“ u pogledu njihovog stava u pogledu njihovog stava po pitanju ekoturizma.

Ključne riječi: ekoturizam, privredni i ekonomski razvoj, upravljanje 